\title{
TRANSFORMATIONAL AND TRANSACTIONAL LEADERSHIP STYLES TOWARDS ORGANIZATIONAL COMMITMENT IN THE HOTEL INDUSTRY
}

\author{
Toh Pei Sung 1 \\ Faculty of Business, Economics and Accountancy, Universiti Malaysia Sabah (UMS), Malaysia. \\ (Email: tohpeisung@ums.edu.my) \\ Liew Wan Joo ${ }^{2}$ \\ Faculty of Business, Economics and Accountancy, Universiti Malaysia Sabah (UMS), Malaysia. \\ (Email: liewwanjoo@gmail.com) \\ Iklima Husna Abdul Rahim ${ }^{3}$ \\ Faculty of Business, Economics and Accountancy, Universiti Malaysia Sabah (UMS), Malaysia. \\ (Email: iklima.husna@ums.edu.my) \\ Stephen Sondoh ${ }^{4}$ \\ Faculty of Business, Economics and Accountancy, Universiti Malaysia Sabah (UMS), Malaysia. \\ (Email: jude@ums.edu.my)
}

Received date: $31-10-2019$

Revised date: 03-11-2019

Accepted date: 07-12-2019

Published date: 10-12-2019

To cite this document: Toh, P. S., Liew, W. J., Rahim, I. H. A., \& Stephen, S. (2019). Transformational and Transactional Leadership Styles towards Organizational Commitment in the Hotel Industry. Journal of Tourism, Hospitality and Environment Management, 4(17), 3445 .

DOI: $10.35631 / J T H E M .417004$

Abstract: In the hotel industry, high service quality has become a concern to the hotel service providers as a means for gaining a competitive advantage since hotels provide similar services. Apart from that, hotels need to have committed staff towards improving the quality of service. In this context, the organizational commitment of operational employees is necessary for providing better services for the guest. The leadership styles in the hotel industry can provide different motivators that leads to organizational commitment. Therefore, the purpose of the study is to examine the perception of the relationship between leadership styles (transformational and transactional) and organizational commitment. The quantitative approach was applied in this study by using questionnaires through a survey. The data analysis was tested by using the SmartPLS 3.0 software. The results suggested that transactional leadership style and transformational leadership styles have a positive relationship with organizational commitment.

Keywords: Transactional, Transformational, Organizational Commitment, Leadership, Hotel

\section{Introduction}

The Malaysian Tourism industry, which was recognised as one of the National Key Economic Areas in Malaysia's vision and hence, putting greater effort to promote Malaysian Tourism 
industry as a tourist destination in order to achieve the vision, a high-income nation by 2020 . The Vision 2020 is to achieve 36 million tourist arrivals and RM 168 billion tourist receipts (Tourism Malaysia, 2018). According to Ministry of Tourism, Culture and Environment, Sabah, which the tourism industry in Sabah is booming, thus, accommodation is utmost important (New Straits Times, 2018). Therefore, the establishment of hotels as an accommodation is getting increase as the movement of people within the domestic and from the foreign for the purposes such as business or pleasure.

As hotels provide similar and identical services, high service quality has become the essential factors in gaining competitive advantage and differentiates themselves from other hotel service providers (Ma \& Qu, 2011). In order to provide high service quality, hotels need to have committed and loyal employees that can provide better services for the guests (Nasurdin, Ahmad \& Tan, 2015). According to Nor Azila, Azilah, Cezar \& Azli, (2010) stated that low organization commitment can impact the level of customer-orientation behavior, especially service-based organization such as hotel. Tracey \& Hinkin (1996) recommended improving service quality through effective leadership, given the labor intensive nature of tourism and hospitality industries and the rapidly changing industry environment in using human capital.

According to As-Sadeq \& Khoury (2006) stated that leadership styles have significant influence on employee outcomes. There are increasing of research interest related to the impact of transformational leadership style and transactional leadership style on employee outcomes such as organizational commitment and performance in hospitality environments (Boyne, 2010 \& Brownell, 2010). However, both leaderships styles may enhance different effect in different settings (Dai, Dai, Chen \& Wu, 2013). Furthermore, leadership can be used as an antecedent variable for organizational commitment (Meyer \& Allen, 1997). Therefore, the aims of this study are to investigate the relationship between leadership styles and organizational commitment in the context of Sabah hotel industry. Specifically, these studies are (1) to examine transactional leadership style and organizational commitment; and (2) to examine the relationship between transformational leadership style and organizational commitment.

\section{The Concept of Organizational Commitment}

According to Allen \& Meyer, (1990) stated that affective commitment, normative commitment and continuance commitment are the three-dimensional approaches that most widely used model in organizational commitment. Organizational commitment is reflected in three key points, which are active association with the organization, the predictable costs of leaving the organization and the obligation to remain in the organization (Meyer \& Allen, 1991). Affective commitment is regarded as an emotional attachment, which strongly committed individual identifies them as involved and likes to be part of the organization (Allen \& Meyer, 1990). Employees who had affective commitment would firstly believe in the organizational values and goals, secondly, they would work hard for the organization and thirdly intend to stay with the organization (Mowday, Porter \& Steers, 1982). Smith \& Hall, (2008) stated that affective commitment appears when an employee wanted to be the part of the profession due to the desired goals.

For normative commitment, it has been viewed as a belief about one's responsibility to the organization and continuance commitment, on the other hand, viewed as the costs that employees associate with leaving the organization (Allen \& Meyer, 1990). According to Marsh \& Mannari, (1977) stated that the normative commitment appears when an individual's perception of their moral obligation to remain with an organization without seeing how much status improvement or fulfilment the organization gives to the employees during his or her term 
in the organization. This is in line with Smith \& Hall, (2008) stated that normative commitment emerges from the awareness on the responsibility for a commitment.

Continuance commitment, on the other hand, is based on the perceived economic and social cost of leaving the organization (Allen \& Meyer, 1990), which number of investment employees make in their current organization and perceived lack of alternatives after leaving the organization. This is in line with Varsha \& Monica, (2012), mentioned that continuance commitment includes the attractive benefits of the current organization, the threat of wasting time and effort to get a new job and disrupt personal relationship. Smith \& Hall, (2008) stated that continuance commitment is the time when people feel that they should stay in that profession due to an accumulation of capital or lack of comparable alternatives.

\section{The Concept of Transformational Leadership Style}

Transformational leadership style is regarded as the leaders motivate subordinates and appeal to their ideals and moral values by creating and representing an inspiring vision of the future (Bass \& Avolio, 1997). Bass \& Avolio, (1997) further that it involves the creation of an emotional attachment between leaders and employees. In this study, transformational leadership style is viewed as identifying and articulating a vision, providing an appropriate model, fostering the acceptance of group goals, setting high performance expectations, and providing individualized support (Podsakoff, MacKenzie, Moorman \& Fetter, 1990).

\section{The Concept of Transactional Leadership Style}

Transactional leadership style is regarded as trades between the leader and follower by which followers are rewarded for meeting specific goals or performance criteria (Trottier, Van Wart \& Wang, 2008). According to Bass \& Avolio, (1994), transactional leadership depends on contingent reinforcement, either positive contingent reward or negative active or passive forms of management by exception. Bass \& Avolio, (1995) explained that transactional leader encourages the participation of employees through both rewards and punishments. In this study, the transactional leadership style is viewed as contingent reward, which involves leaders clarifying roles and task expectations and providing contingent rewards on the fulfilment of contractual obligations, as the leader behavior (Podsakoff, MacKenzie, Moorman \& Fetter, 1990).

\section{Transactional Leadership Style and Organizational Commitment}

According to Bass, Avolio, Jung \& Berson, (2003), several previous studies found a positive relationship between transactional and organizational commitment. This is in line with Chiang \& Jang, (2008) and Uen, Wu, Teng \& Liu, (2012) found that transactional leadership style has a positive relationship with organizational commitment. However, transactional leadership style has found associated negatively with organizational commitment (Dai et al., 2013) which contrary to Mardiyana, Owin \& Juhary, (2019) that transactional leadership style has a positive relationship with organizational commitment. Therefore, this study attempts to test the following hypothesis:

H1: There is a positive relationship between transactional leadership style and organizational commitment.

\section{Transformational Leadership Style and Organizational Commitment}

There are other fields of research found that transformational leadership style has a positive relationship with organizational commitment (Jackson, Meyer \& Wang, 2013; Judge \& Piccolo, 2004; Pillai \& Williams, 2004). This is in line with Chiang \& Jang, (2008); Uen et al., 
(2012) and Tuna, Ghazzawi, Tuna \& Çatir, (2011) found that transformational leadership style has a positive relationship with organizational commitment. This is also supported by Rini \& Diana, (2019) that transformational leadership style has found associated positively with organizational commitment. Therefore, this study attempts to test the following hypothesis:

$\mathrm{H} 2$ : There is a positive relationship between transformational leadership style and organizational commitment.

\section{Methodology}

The study has been conducted in Kota Kinabalu, Sabah with the aim to examine the relationship between leadership styles (transactional and transformational) and organizational commitment in 3-5 star rated hotels. The study used the quantitative approach and used the structured questionnaire as the research instrument. The target population of this study is the employees working in operational departments such as food and beverage department, housekeeping department and front office department. The sample size is 138 for this study as per G power analysis. The respondents were chosen by using purposive sampling technique. A drop-off and pick-up method were used to collect data. A total of 145 questionnaires were distributed and the usable questionnaires from the survey, yielding response rate of 95.86 percent. The study used a five-point Likert scale in the survey instrument, which ranging from strongly disagree (1) to strongly agree (5). The measurement items of variable transformational and variable transactional adapted from Podsakoff, MacKenzie, Moorman \& Fetter (1990) as presented in Table 1 and Table 2 respectively. Organizational commitment was measured from 3 dimensions [namely, affective commitment; continuance commitment and normative commitment] that adapted from Allen \& Meyer, (1990) as presented in Table 3, Table 4 and Table 5 respectively.

\section{Table 1: Measurement Items for Transformational Leadership Style}

\begin{tabular}{lll} 
No. & \multicolumn{1}{c}{ Items } & \multicolumn{1}{c}{ Source } \\
\hline 1. & $\begin{array}{l}\text { My manager is always seeking new opportunities for the } \\
\text { unit/department/organization. }\end{array}$ & $\begin{array}{c}\text { Podsakoff, } \\
\text { MacKenzie, Moorman } \\
\text { \& Fetter (1990) }\end{array}$ \\
\hline 2. & My manager provides a good model to follow. \\
\hline 3. & My manager encourages employees to be team players. \\
\hline 4. & My manager shows us that he/she expects a lot from us. \\
\hline 5. & My manager acts without considering my feelings. (R) &
\end{tabular}

Table 2: Measurement Items for Transactional Leadership Style

\begin{tabular}{llc}
\hline No. & \multicolumn{1}{c}{ Items } & \multicolumn{1}{c}{ Source } \\
\hline 1. & $\begin{array}{l}\text { My manager always gives me positive feedback when I } \\
\text { perform well. }\end{array}$ & $\begin{array}{c}\text { Podsakoff, } \\
\text { MacKenzie, Moorman } \\
\text { \& Fetter (1990) }\end{array}$ \\
2. & $\begin{array}{l}\text { My manager gives me special recognition when my work is } \\
\text { very good. }\end{array}$ & \\
3. & $\begin{array}{l}\text { My manager commends me when I do a better than average } \\
\text { job. }\end{array}$
\end{tabular}


4. My manager personally compliments me when I do outstanding work.

5. My manager frequently does not acknowledge my good performance. (R)

Table 3: Measurement Items for Affective Commitment

\begin{tabular}{llc}
\hline No. & \multicolumn{1}{c}{ Items } & Source \\
\hline 1. & $\begin{array}{l}\text { I would be very happy to spend the rest of my career } \\
\text { with this organization. }\end{array}$ & $\begin{array}{c}\text { Allen and Meyer } \\
\text { (1990) }\end{array}$ \\
2. & $\begin{array}{l}\text { I enjoy discussing about my organization with people } \\
\text { outside it. }\end{array}$ \\
3. & I really feel as if this organization's problems are my own. \\
4. & I think that I could easily become as attached to another \\
organization as I am to this one. (R)
\end{tabular}

Table 4: Measurement Items for Continuance Commitment

\begin{tabular}{|c|c|c|}
\hline No. & Items & Source \\
\hline 1. & $\begin{array}{l}\text { I am not afraid of what might happen if I quit my job without } \\
\text { having another one lined up. (R) }\end{array}$ & $\begin{array}{l}\text { Allen and Meyer } \\
(1990)\end{array}$ \\
\hline 2. & $\begin{array}{l}\text { It would be very hard for me to leave my organization right now, } \\
\text { even if I wanted to. }\end{array}$ & \\
\hline 3. & $\begin{array}{l}\text { Too much in my life would be disrupted if I decided to leave my } \\
\text { organization now. }\end{array}$ & \\
\hline 4. & $\begin{array}{l}\text { It wouldn't be too costly for me to leave my organization now. } \\
\text { (4) }\end{array}$ & \\
\hline 5. & $\begin{array}{l}\text { Right now, staying with my organization is a matter of necessity } \\
\text { as much as desire. }\end{array}$ & \\
\hline 6. & $\begin{array}{l}\text { I feel that I have very few options to consider leaving this } \\
\text { organization. (6) }\end{array}$ & \\
\hline 7. & $\begin{array}{l}\text { One of the few serious consequences of leaving this } \\
\text { organization would be the scarcity of available alternatives. }\end{array}$ & \\
\hline 8. & $\begin{array}{l}\text { One of the major reasons I continue to work for this organization } \\
\text { is that leaving would require considerable personal sacrifice - } \\
\text { another organization may not match the overall benefits I have } \\
\text { here. }\end{array}$ & \\
\hline
\end{tabular}


Table 5: Measurement Items for Normative Commitment

\begin{tabular}{|c|c|c|}
\hline No. & Items & Source \\
\hline 1. & $\begin{array}{l}\text { I think that people these days move from company to company } \\
\text { too often. }\end{array}$ & $\begin{array}{c}\text { Allen and Meyer } \\
(1990)\end{array}$ \\
\hline 2. & $\begin{array}{l}\text { I do not believe that a person must always be loyal to his or her } \\
\text { organization. (R) }\end{array}$ & \\
\hline 3. & $\begin{array}{l}\text { Jumping from organization to organization does not seem at all } \\
\text { unethical to me. }(\mathrm{R})\end{array}$ & \\
\hline 4. & $\begin{array}{l}\text { One of the major reasons I continue to work in this organization } \\
\text { is that I believe loyalty is important and therefore fell a sense of } \\
\text { moral obligation to remain. }\end{array}$ & \\
\hline 5. & $\begin{array}{l}\text { If I got another offer for a better job elsewhere I would not feel } \\
\text { it was right to leave my organization. }\end{array}$ & \\
\hline 6. & $\begin{array}{l}\text { I was taught to believe in the value of remaining loyal to one } \\
\text { organization. }\end{array}$ & \\
\hline 7. & $\begin{array}{l}\text { Things were better in the days when people stayed in one } \\
\text { organization for most of their careers. }\end{array}$ & \\
\hline 8. & $\begin{array}{l}\text { I do not think that to be a 'company man' or 'company woman' } \\
\text { is sensible anymore. }(\mathrm{R})\end{array}$ & \\
\hline
\end{tabular}

\section{Assessment of Measurement Model}

The measurement model is examined for the internal consistency reliability, convergent validity, and discriminant validity. Consistency reliability of the constructs is examined through the Cronbach's alpha, composite reliability and Rho (Hair, Hult, Ringle \& Sarstedt, 2017; Dijkstra \& Henseler, 2015b). Moreover, convergent validity of the constructs is examined through the outer loadings, and average variance extracted (AVE) (Hair et al., 2017; Hair, Hult, Ringle \& Sarstedt, 2014). On the other hand, discriminant validity of the constructs is examined using cross-loadings, Forner-Lacker criterion, and HTMT as suggested by Hair et al., (2017) and Henseler, Ringle \& Sarstedt, (2015).

The threshold value is 0.70 for Cronbach's alpha, composite reliability and Rho that indicates internal consistency (Ramayah, Cheah, Chuah, Ting \& Memon, 2018). All the constructs involved in this study exceeded the threshold criterion. For outer loadings, the threshold value is 0.70 and for AVE, the threshold value is 0.50 , which suggested an adequate convergent validity (Hair et al., 2017; Hair, Black, Babin, Anderson, \& Tatham, 2010; Bagozzi \& Yi, 1988; Byrne, 2016). All the constructs involved in this study were exceeded the threshold criterion. Table 6 shows the Cronbach's alpha, composite reliability, RhoA, outer loadings, and average variance extracted (AVE) for all the constructs. 
Table 6: Assessment of Outer Loadings, Cronbach's Alpha, RhoA, Composite Reliability and AVE

\begin{tabular}{lcccccc}
\hline Constructs & Items & $\begin{array}{c}\text { Outer } \\
\text { Loadings }\end{array}$ & $\begin{array}{c}\text { Cronbach's } \\
\text { Alpha }\end{array}$ & Rhos & $\begin{array}{c}\text { Composite } \\
\text { Reliability }\end{array}$ & $\begin{array}{c}\text { Average } \\
\text { Variance } \\
\text { Extracted } \\
\text { AVE }\end{array}$ \\
\hline Transformational & TFLS1 & 0.746 & 0.791 & 0.793 & 0.865 & 0.616 \\
& TFLS2 & 0.837 & & & & \\
& TFLS3 & 0.806 & & & & \\
Transactional & TFLS4 & 0.746 & & & & 0.672 \\
& TSLS1 & 0.806 & 0.878 & 0.883 & 0.911 & \\
& TSLS2 & 0.788 & & & & \\
TSLS3 & 0.848 & & & & \\
Organizational & TSLS4 & 0.817 & & & & \\
Commitment & TSLS5 & 0.840 & & & & \\
& AC & 0.792 & 0.756 & 0.766 & 0.859 & \\
\hline
\end{tabular}

Note: TFLS5 item for transformational construct is deleted due to the outer loading is not more than 0.5.

In assessing the cross-loadings, each indicator should load high on its own constructs but low on other constructs. Table 7 shows that each indicator is high on its respective construct than its cross-loadings on any other constructs.

Table 7: Cross-Loadings

\begin{tabular}{lccc}
\hline & COMMITMENT & TRANSFORMATIONAL & TRANSCATIONAL \\
\hline AC & $\mathbf{0 . 7 9 2}$ & 0.459 & 0.432 \\
CC & $\mathbf{0 . 8 2 3}$ & 0.394 & 0.509 \\
NC & $\mathbf{0 . 8 4 2}$ & 0.498 & 0.588 \\
TSLS1 & 0.393 & $\mathbf{0 . 7 4 6}$ & 0.477 \\
TSLS2 & 0.444 & $\mathbf{0 . 8 3 7}$ & 0.540 \\
TSLS3 & 0.415 & $\mathbf{0 . 8 0 6}$ & 0.417 \\
TSLS4 & 0.471 & $\mathbf{0 . 7 4 6}$ & 0.418 \\
TSLS5 & 0.491 & 0.540 & $\mathbf{0 . 8 0 6}$ \\
TFLS1 & 0.441 & 0.417 & $\mathbf{0 . 7 8 8}$ \\
TFLS2 & 0.527 & 0.486 & $\mathbf{0 . 8 4 8}$ \\
TFLS3 & 0.535 & 0.479 & $\mathbf{0 . 8 1 7}$ \\
TFLS4 & 0.568 & 0.492 & $\mathbf{0 . 8 4 0}$ \\
\hline
\end{tabular}

The Fornell-Larcker criterion, where the square root of AVE (diagonal) is larger than its correlations (off-diagonal) for all constructs. Table 8 shows that the square root of AVE of each of the constructs is larger than its correlations with other constructs. 


\section{COMMITMENT}

TRANSCATIONAL TRANSFORMATIONAL
COMMITMENT TRANSCATIONAL

\subsection{9}

0.629

0.552 $\mathbf{0 . 8 2 0}$

0.590

TRANSFORMATIONAL

The values are lower than the required threshold value of HTMT that suggested by Henseler $e t$ al., (2015), which is 0.90 and the confidence interval does not show a value of one on any of the constructs, indicating the discriminant validity. Table 9 shows the values has fulfilled HTMT criterion.

Table 9: HTMT Result

COMMITMENT TRANSCATIONAL TRANSFORMATIONAL

\section{COMMITMENT}

TRANSCATIONAL

TRANSFORMATIONAL
CI $0.90(0.321,0.584)$

0.706

CI $0.90(0.163,0.375)$
0.707

CI $0.90(0.471,0.683)$

\section{Structural Model Assessment}

The collinearity issue needs to be assessed in the initial stage of assessing structural model by looking at the VIF value. The collinearity issue exists when a VIF value is higher than 5 (Hair et al., 2017). Table 10 shows that all the Inner VIF values for the independent variables (Transformational and Transactional) are less than 5, thus indicating collinearity is not an issue.

\section{COMMITMENT}

The coefficient of determination, $\mathrm{R}^{2}$ represents the amount of variance in the endogenous (Organizational Commitment) explained by all of the exogenous constructs linked to it (Transactional and Transformational). According to Chin, (1998) stated that 0.67, 033, 019 respectively, describing substantial, moderate, or weak levels of predictive accuracy. Table 11 shows the $\mathrm{R}^{2}$ values, which is 0.445 , implying that $44.5 \%$ of organizational commitment is predicted by transactional and transformational leadership styles.

Table 11: $\mathbf{R}^{2}$ Values

\begin{tabular}{|c|c|}
\hline Construct & $\mathbf{R}^{\mathbf{2}}$ \\
\hline Organizational Commitment & 0.445 \\
\hline
\end{tabular}

Next, the assessment of the structural model for examining the hypothesized relationships among the constructs through a bootstrapping procedure with 5000 sub samples (Hair et al., 2017). The path coefficients are obtained for the structural model relationships, which represent the hypothesized relationships that link the constructs by looking at the beta $(\beta), R^{2}$, and the corresponding t-values (Hair et al., 2017; Hair, Ringle \& Sarstedt, 2011). Table 12 shows the 
significance results of the structural model. All the hypothesized relationships are supported at $\mathrm{p}<0.01$.

Table 12: Results of the Structural Model

\begin{tabular}{|c|c|c|c|c|c|c|c|c|}
\hline Hypothesis & Path & $\begin{array}{c}\text { Std } \\
\text { Beta } \\
(\beta) \\
\end{array}$ & $\begin{array}{c}\text { Std } \\
\text { Error }\end{array}$ & t-values ${ }^{a}$ & p-values & LL & UL & Decision \\
\hline H1 & $\begin{array}{l}\text { TRANSCATIONAL } \\
\text {-> COMMITMENT }\end{array}$ & 0.465 & 0.079 & $5.892 * *$ & 0.000 & 0.315 & 0.577 & Supported \\
\hline H2 & $\begin{array}{l}\text { TRANSFORMATIONAL } \\
->\text { COMMITMENT }\end{array}$ & 0.278 & 0.064 & $4.319 * *$ & 0.000 & 0.162 & 0.376 & Supported \\
\hline
\end{tabular}

*Significant at $\mathrm{p}<0.05 ; * *$ Significant at $\mathrm{p}<0.01$

Notes: $(\mathrm{t}(4999)$, One tailed test: $\mathrm{t}(0.05 ; 4999)=1.65 ; \mathrm{t}(0.01 ; 4999))=2.33$

\section{Discussions and Conclusions}

The aims of this study are to examine the relationships between leadership styles and organizational commitment. Specifically, it attempts (1) to examine the relationship between transactional leadership style and organizational commitment; and (2) to examine the relationship between transformational leadership style and organizational commitment. All hypothesized relationships are supported, and t-values are statistically significant. Besides, the results demonstrated good measurement model in terms of internal consistency, convergent validity and discriminant validity.

The results have demonstrated a positive direct relationship between transactional leadership style and organizational commitment. This indicates that a leader who understanding, providing and committing in terms of employee needs and reward leads to an employee who wants to and feel accepted, perceived the benefit of effort, obligation and loyalty to organization by willingness to contribute and work hard to achieve organizational goals.

Besides, the results have showed a positive direct relationship between transformational leadership style and organizational commitment. This indicates that a leader who stimulate interest, generate awareness, develop higher performance and motivate to take highest advantage of opportunities, which leads to an employee who wants to have sense of acceptance, the benefit of contribution, obligation and loyalty to organization by willingness for being a competitive employee to achieve organizational goals.

Both transactional and transformational have been considered as the important contemporary leadership styles, that leads to organizational commitment in the hotel industry. Previous studies have reported different results on the effect of both transactional and transformational leadership styles on organizational commitment. According to Chiang \& Jang (2008) and Uen et al., (2012) that transactional and transformational leadership styles have been found associated positively with organizational commitment. However, transactional leadership style has found associated negatively with organizational commitment (Dai et al., 2013). Besides, transformational leadership style has found associated positively with organizational commitment (Tuna et al., 2011).

To conclude, transactional and transformational leadership styles should not be viewed as mutually contradictory, but as complementary, which the best leaders should have both transactional and transformational qualities (Chiang \& Wang, 2012). Besides, this study would have added value to the literatures on leadership styles and organizational commitment, 
especially in Sabah hotel industry settings.

\section{References}

Allen, N. J., \& Meyer, J. P. (1990). The Measurement and Antecedents of Affective, Continuance and Normative Commitment to The Organization. Journal of Occupational Psychology, 63(1), 1-18. doi:10.1111/j.2044-8325. 1990.tb00506.x

As-Sadeq, H. A., \& Khoury, G. C. (2006). Leadership Styles in The Palestinian Large-Scale Industrial Enterprises. Journal of Management Development, 25(9), 832-849. doi:10.1108/02621710610692043

Bagozzi, R. P., \& Yi, Y. (1988). On the Evaluation of Structural Equation Models. Journal of the Academy of Marketing Science, 16(1), 74-94.

Bass, B. M., Avolio, B. J., Jung, D. I., \& Berson, Y. (2003). Prediction Unit Performance by Assessing Transformational and Transactional Leadership. Journal of Applied Psychology, 88(2), 207-218. http://dx.doi.org/10.1037/0021-9010.88.2.207

Bass, B. M., \& Avolio, B. J. (1997). Full Range Leadership Development: Manual for The Multifactor Leadership Questionnaire. Palo Alto, CA: Mind Garden.

Bass, B. M., \& Avolio, B. J. (1995). Multifactor Leadership Questionnaire. Redwood City, CA: Mind Garden.

Bass, B.M. \& Avolio, B.J. (1994). Improving Organizational Effectiveness Through Transformational Leadership, Sage, Thousand Oaks, CA.

Boyne, S. (2010). Leadership Research in Hospitality: A Critical Review, paper presented at BAM 2010 Conference, University of Sheffi, 14-16 September.

Brownell, J. (2010). Leadership in the Service of Hospitality. Cornell Hospitality Quarterly, 51(3), 363-378. doi:10.1177/1938965510368651

Byrne, B. (2016). Structural Equation Modeling with AMOS: Basic Concepts, Applications and Programming. Mahwah, New Jersey, London: Lawrence Erlbaum Associates.

Chiang, C. F., \& Jang, S. (2008). The Antecedents and Consequences of Psychological Empowerment: The Case of Taiwan's Hotel Companies. Journal of Hospitality \& Tourism Research, 31(1), 40-61.

Chiang, C., \& Wang, Y. (2012). The Effects of Transactional and Transformational Leadership on Organizational Commitment in Hotels: The Mediating Effect of Trust. Journal of Hotel \& Business Management, 1(1). doi:10.4172/2169-0286.1000103

Chin, W. W. (1998). The partial least squares approach for structural equation modeling. In G. A. Marcoulides (Ed.), Methodology for business and management. Modern methods for business research (295-336). Mahwah, NJ, US: Lawrence Erlbaum Associates Publishers.

Dai, Y., Dai, Y., Chen, K., \& Wu, H. (2013). Transformational Vs. Transactional Leadership: Which Is Better? A Study on Employees of International Tourist Hotels in Taipei City. PsycEXTRA Dataset. doi:10.1037/e610182012-002

Dijkstra, T. K., \& Henseler, J. (2015b). Consistent Partial Least Squares Path Modeling. MIS Quarterly, 39(2), 297-316. doi:10.25300/misq/2015/39.2.02

Hair, J. F., Hult, G. T. M., Ringle, C. M., \& Sarstedt, M. (2017). A Primer on Partial Least Squares Structural Equation Modeling. 2nd Ed. Thousand Oaks: Sage.

Hair, J. F., Hult, G. T. M., Ringle, C., \& Sarstedt, M. (2014). A Primer on Partial Least Squares Structural Equation Modeling (PLS-SEM): Sage Publications.

Hair, J. F., Ringle, C. M., \& Sarstedt, M. (2011). PLS-SEM: Indeed a Silver Bullet. Journal of Marketing Theory and Practice, 19(2), 139-152. doi:10.2753/mtp1069-6679190202

Hair, J. F., Black, W. C., Babin, B. J., Anderson, R. E., Tatham, R. L. (2010). Multivariate Data Analysis. 7th ed. New York: Pearson. 
Henseler, J., Ringle, C. M., \& Sarstedt, M. (2015). A New Criterion for Assessing Discriminant Validity in Variance-Based Structural Equation Modeling. Journal of the Academy of Marketing Science, 43(1), 115-135. doi:10.1007/s11747-014-0403-8

Jackson, T. A., Meyer, J. P., \& Wang, X.-H. (2013). Leadership, Commitment and Culture: A Meta-Analysis. Journal of Leadership \& Organizational Studies, 20(1), 84-106.

Judge, T. A., \& Piccolo, R. F. (2004). Transformational and Transactional Leadership: A MetaAnalytic Test of Their Relative Validity. Journal of Applied Psychology, 89(5), 755768. doi:10.1037/0021-9010.89.5.755

Ma, E., \& Qu, H. (2011). Social Exchanges as Motivators of Hotel Employees' Organizational Citizenship Behavior: The Proposition and Application of a New Three-Dimensional Framework. International Journal of Hospitality Management, 30(3), 680-688. doi: 10.1016/j.ijhm.2010.12.003

Mackenzie, S. B., Podsakoff, P. M., \& Rich, G. A. (2001). Transformational and Transactional Leadership and Salesperson Performance. Journal of the Academy of Marketing Science, 29(2), 115-134. doi:10.1177/03079459994506

Mardiyana, Owin, J. D., \& Juhary, A. (2019). The Effect of Transformational and Transactional Leadership on The Commitment of Organization, Turnover, And Performance (At Baitul Maal Wat Tamwil, The Special Region of Yogyakarta). IOSR Journal of Business and Management, 21(3), 9-17.

Marsh, R. M., \& Mannari, H. (1977). Organizational Commitment and Turnover: A Prediction Study. Administrative Science Quarterly, 22(1), 57. doi:10.2307/2391746

Meyer, J. P., \& Allen, N. J. (1997). Commitment in the workplace: Theory, research, and application. Thousand Oaks, CA: Sage Publ.

Meyer, J. P., \& Allen, N. J. (1991). A Three-Component Conceptualization of Organizational Commitment. Human Resource Management Review, 1(1), 61-89. doi:10.1016/10534822(91)90011-z

Mowday, R. T., Porter, L. W., \& Steers, R. M. (1982). Consequences of Employee Commitment, Turnover, and Absenteeism. Employee-Organization Linkages, 135168. doi:10.1016/b978-0-12-509370-5.50010-1

Nasurdin, A. M., Ahmad, N. H., \& Tan, C. L. (2015). Cultivating Service-Oriented Citizenship Behavior Among Hotel Employees: The Instrumental Roles of Training and Compensation. Service Business, 9(2), 343-360. doi:10.1007/s11628-014-0230-5

New Straits Times. (2018, April 30). Retrieved from https://www.nst.com.my/

Nor Azila, M. N., Azilah, K., Cezar, S., \& Azli, M. (2010). Importance of Organizational Commitment, Job Motivation and Front Liners Self Efficacy Towards the Marketability of Hotel Industry in Kuala Lumpur Malaysia. Academica Turistica, 64-72.

Pillai, R., \& Williams, E. A. (2004). Transformational Leadership, Self-Efficacy, Group Cohesiveness, Commitment and Performance. Journal of Organizational Change Management, 17(2), 144-159. http://dx.doi.org/10.1108/09534810410530584

Podsakoff, P. M., Mackenzie, S. B., Moorman, R. H., \& Fetter, R. (1990). Transformational Leader Behaviors And Their Effects on Followers Trust in Leader, Satisfaction, And Organizational Citizenship Behaviors. The Leadership Quarterly, 1(2), 107-142. doi:10.1016/1048-9843(90)90009-7

Ramayah, T., Cheah, J., Chuah, F., Ting, H., \& Memon, M. A. (2018). Partial Least Squares Structural Equation Modeling (PLS-SEM) Using SmartPLS 3.0: An Updated and Practical Guide to Statistical Analysis. (2nd edition) Singapore: Pearson.

Rini, R., \& Diana, K. S. (2019). The Role of Transformational Leadership on Organizational Commitment and Job Satisfaction of Tax Office Officers (KPP) In Banjarmasin. International Journal of Scientific \& Technology Research, 8(7), 11-17. 
Smith, D., \& Hall, M. (2008). An Empirical Examination of a Three-Component Model of Professional Commitment among Public Accountants. Behavioral Research in Accounting, 20(1), 75-92. doi:10.2308/bria.2008.20.1.75

Tracey, J., \& Hinkin, T. R. (1996). How Transformational Leaders Lead in The Hospitality Industry. International Journal of Hospitality Management, 15(2), 165-176. doi:10.1016/0278-4319(95)00059-3

Tourism Malaysia. (2018). Retrieved from https://www.tourism.gov.my/

Trottier, T., Van Wart, M., \& Wang, X. H. (2008). Examining the Nature and Significance of Leadership in Government Organizations. Public Administration Review, 68, 319-333.

Tuna, M., Ghazzawi, I., Tuna, A. A., \& Çatir, O. (2011). Transformational Leadership and Organizational Commitment: The Case of Turkey's Hospitality Industry. S.A.M. Advanced Management Journal, 76(3), 10-25.

Uen, J., Wu, T., Teng, H., \& Liu, Y. (2012). Transformational Leadership and Branding Behavior In Taiwanese Hotels. International Journal of Contemporary Hospitality Management, 24(1), 26-43. doi:10.1108/09596111211197782

Varsha, D., \& Monika, B. (2012). A Study About Employee Commitment and Its Impact on Sustained Productivity in Indian Auto-Component Industry. European Journal of Business and Social Sciences, 1(6), 34-51. 